\title{
Adam Radzimski
}

Uniwersytet im. Adama Mickiewicza w Poznaniu

Instytut Geografii Spoteczno-Ekonomicznej i Gospodarki Przestrzennej

adam.radzimski@amu.edu.pl

Gran Sasso Science Institute, Urban Studies Unit (GSSI Cities), L'Aquila, Włochy

adam.radzimski@gssi.infn.it

\section{Regionalne zróżnicowanie polityki mieszkaniowej. Przykład programu „Rodzina na swoim”}

\begin{abstract}
Zarys treści: Celem niniejszego artykułu jest odpowiedź na pytanie, jakie bylo zróżnicowanie regionalne pomocy państwa udzielonej w formie dopłat do kredytów hipotecznych w ramach programu „Rodzina na swoim”. Analiza prowadzona jest na poziomie województw oraz miast wojewódzkich. W świetle uzyskanych wyników stwierdzić można, że efekty programu „Rodzina na swoim” wykazują istotne zróżnicowanie regionalne. Zauważalna jest przy tym prawidłowość, że pomoc państwa była większa w dużych miastach oraz regionach o wyższym poziomie rozwoju społeczno-gospodarczego. Wyniki przeczą obiegowej opinii, jakoby mieszkańcy największych miast w niewielkim stopniu skorzystali z doplat ze względu na niedostosowanie limitów cenowych do poziomu cen rynkowych. Przeciwnie, to właśnie miasta wojewódzkie, a zwłaszcza Warszawa, Wrocław, Kraków, Poznań i Gdańsk, okazały się największymi beneficjentami tej polityki.
\end{abstract}

Słowa kluczowe: polityka mieszkaniowa, kredyty hipoteczne, zróżnicowanie regionalne, rozwój regionalny

\section{Wprowadzenie}

Pomimo dynamicznie rozwijającego się w ostatnich latach rynku deweloperskiego sytuacja mieszkaniowa w Polsce pozostaje w znacznym stopniu niezadowalająca. Polska znajduje się w gronie państw członkowskich Unii Europejskiej, w których liczba mieszkań przypadająca na 1000 mieszkańców jest najmniejsza (Ministry of the Interior... 2010, Radzimski 2014), a ceny mieszkań w Polsce w relacji do przeciętnych wynagrodzeń są wysokie. Trudne warunki mieszkaniowe to problem dotyczący w największym stopniu osób młodych. Brak możliwości przeprowadzenia się do własnego mieszkania negatywnie rzutować może na istotne życiowe decy- 
zje, dotyczące np. podjęcia bardziej atrakcyjnej pracy w innym mieście, zawarcia małżeństwa czy posiadania dzieci.

Zaangażowanie państwa $\mathrm{w}$ politykę mieszkaniową nie było w Polsce $\mathrm{w}$ okresie po 1989 r. zbyt duże. Okres transformacji gospodarczo-ustrojowej zbiegł się $\mathrm{w}$ czasie $\mathrm{z}$ upowszechnieniem się neoliberalnych poglądów na rolę państwa $\mathrm{w}$ gospodarce, w myśl których sfera potrzeb mieszkaniowych powinna być zasadniczo domeną wolnego rynku. Po części z tego względu, a po części z bardziej pragmatycznego powodu, jakim była trudna sytuacja gospodarcza i finansowa państwa po upadku socjalizmu, środki wydatkowane na politykę mieszkaniową z budżetu państwa (a także budżetów samorządów, na które scedowano odpowiedzialność za tę dziedzinę w znacznym zakresie) były dość ograniczone. Było też wszakże kilka wyjątków. Jedną z najbardziej znaczących interwencji państwa na rynku mieszkaniowym w ostatnich latach był program dopłat do kredytów hipotecznych, powszechnie znany pod nazwą ,Rodzina na swoim”.

Stworzenie programu takiego jak "Rodzina na swoim” było wyrazem dostosowania się do sytuacji. W Polsce $w$ pierwszych latach po zmianie ustroju korzystano $z$ kredytów hipotecznych w marginalnym stopniu. Natomiast w krajach rozwiniętych kredyty hipoteczne są powszechnie stosowaną formą finansowania zakupu mieszkań. Całkowite zadłużenie gospodarstw domowych w krajach Europy Zachodniej czy też USA jest na poziomie kilkudziesięciu procent PKB i jest porównywalne z ich zadłużeniem publicznym. W 1998 r. W Polsce zadłużenie hipoteczne stanowiło tylko 1,9\% PKB, a sześć lat później wskaźnik ten wyniósł $4,7 \%$ PKB. W kolejnych latach tempo wzrostu zostało utrzymane i w $2010 \mathrm{r}$. kredyty hipoteczne stanowily 19,1\% PKB (DICE Database 2012). Program „Rodzina na swoim" został zainicjowany w 2006 r., a zatem w momencie, gdy zaciąganie kredytów hipotecznych w celu sfinansowania zakupu mieszkania stało się zjawiskiem powszechnym. Nabywanie mieszkania z wykorzystaniem kredytu jest atrakcyjnym rozwiązaniem zwłaszcza dla osób młodych, które nie posiadają własnych oszczędności, a w perspektywie mają długi okres aktywności zawodowej, podczas którego są w stanie zarobić na spłatę rat. Głównie z myślą o takich właśnie osobach, przed którymi zaciągnięcie kredytu otwiera nowe możliwości, a jednocześnie stanowi poważne obciążenie finansowe, stworzony został program „Rodzina na swoim”.

Celem niniejszego artykułu jest odpowiedź na pytanie, jakie było regionalne zróżnicowanie pomocy państwa udzielonej w ramach programu „Rodzina na swoim". Kolejne części artykułu zawierają: przegląd literatury, omówienie zasad udzielania pomocy przez państwo, wyniki analizy danych empirycznych oraz wnioski.

\section{Podstawowe informacje o programie}

Program „Rodzina na swoim” został wprowadzony na mocy ustawy o finansowym wsparciu rodzin w nabywaniu własnego mieszkania $z$ dnia 8 września 2006 r. Istotą programu było udzielenie przez państwo dopłat, które pokrywały 
część kosztów odsetek od zaciągniętych przez gospodarstwa domowe kredytów hipotecznych. Pomimo że zasady programu kilkakrotnie ulegały dość istotnym zmianom, jego ogólną ideą była pomoc w nabyciu własnego „M” osobom znajdującym się w niezadowalającej sytuacji mieszkaniowej.

Program był wyrazem nowego podejścia do polityki mieszkaniowej. W PRL ze względów polityczno-ideologicznych posiadanie mieszkań na własność było co najwyżej tolerowane przez władze. W realiach nowego ustroju polityka mieszkaniowa podlegała bardzo częstym zmianom. Ze względu na objętość tekstu, nie sposób przedstawić w tym miejscu wyczerpującego rysu historycznego. Czytelnik szerzej zainteresowany tematem może sięgnąć w tym celu po opracowania przeglądowe (Frąckowiak 2008, Lis 2008). Nie wdając się w szczegóły, stwierdzić można jednak, że z czasem zarysowała się coraz wyraźniejsza tendencja do wspierania przez państwo nabywania mieszkań na własność. Swego rodzaju kulminację tej tendencji stanowił właśnie program „Rodzina na swoim”, a także wprowadzony później program „Mieszkanie dla młodych”. Wcześniejszymi instrumentami najbardziej zbliżonymi do „Rodziny na swoim” były: ulga odsetkowa, obowiązująca w latach 2001-2006, oraz dopłaty do kredytów o stałej stopie procentowej, obowiązujące w latach 2002-2006.

\section{Przegląd literatury}

Jakkolwiek kwestia, czy mieszkanie posiadane na własność jest lepsze od wynajmowanego, nie jest $z$ naukowego punktu widzenia jednoznaczna, zaobserwować można pewną prawidłowość, że wraz ze wzrostem dobrobytu zwiększa się skłonność do nabywania mieszkań na własność. Państwa o wyższym poziomie produktu krajowego brutto na mieszkańca mają wyższy odsetek mieszkań własnościowych, choć od tej reguły są także znaczące wyjątki. Przykładowo bardzo wysokimi odsetkami mieszkań własnościowych odznaczają się kraje postsocjalistyczne, takie jak Rumunia czy Bułgaria, natomiast w Niemczech i Szwajcarii odsetek ten jest relatywnie niski. Zatem czynniki inne niż zamożność także odgrywają pewną rolę, jednakże opisana wyżej zależność bez wątpienia występuje, co potwierdzają chociażby badania prowadzone w krajach OECD (Andrews, Sánchez 2011).

Patrząc w skali europejskiej czy też globalnej, znaleźć można wiele przykładów instrumentów polityki mieszkaniowej zbliżonych pod wieloma względami do „Rodziny na swoim”. Rządy wielu państw prowadziły w niedawnym okresie bądź prowadzą nadal politykę, której celem jest zachęcanie do nabywania mieszkań na własność poprzez stosowanie dopłat do kredytów, względnie ulg podatkowych. Najbardziej znanym przykładem są Stany Zjednoczone, gdzie ulgi podatkowe dla kredytobiorców są istotnym elementem polityki mieszkaniowej i chyba także szeroko rozumianej polityki społecznej (Hanson 2012). Model ten opiera się na założeniu, że należy umożliwić jak największej grupie obywateli nabycie na własność domu finansowanego kredytem hipotecznym. $Z$ kolei koszt odsetek od kredytu częściowo bierze na siebie państwo, które dając kredytobiorcom prawo do ulgi podatkowej, de facto przyznaje im swego rodzaju dotację. Oprócz USA politykę zachęcającą do zaciągania kredytów hipotecznych prowadziło lub 
prowadzi nadal szereg państw zachodnioeuropejskich, w tym Francja, Niemcy oraz Wielka Brytania (Donner 2000), a także kraje pozaeuropejskie, np. Tajwan (Bourassa, Yin 2008). Spośród dawnych krajów socjalistycznych na największą chyba skalę dopłaty do kredytów stosowano na Węgrzech, podczas gdy Czechy postawiły raczej na stworzenie systemu zachęt do oszczędzania na cele mieszkaniowe (Hegedüs i in. 2011).

Pomimo że dopłaty do kredytów są rozwiązaniem chętnie stosowanym przez rządy wielu państw jako sposób na upowszechnienie własności mieszkań wśród gospodarstw domowych o niskich dochodach, w środowisku naukowym instrument ten budzi dość poważne zastrzeżenia (Hamby 2011). Wątpliwości wzbudza przede wszystkim zasadnicza kwestia, a mianowicie czy dopłaty przyczyniają się do poprawy dostępności mieszkań dla osób, które znajdują się w niezadowalającej sytuacji mieszkaniowej. Wyniki badań empirycznych w znacznej części zdają się tego nie potwierdzać, co więcej, niektóre badania sugerują, że ma miejsce efekt wręcz odwrotny, tj. dopłaty skutkować mogą wzrostem cen mieszkań bądź też wyższym oprocentowaniem kredytów, a przez to de facto utrudniać, a nie ułatwiać drogę do nabycia własnego mieszkania (Berger i in. 2000, Bourassa, Yin 2008, Benchetrit, Czamanski 2009). Część autorów mimo wszystko jest zdania, że preferencje ze strony państwa dla kredytobiorców są potrzebnym elementem polityki społecznej, jednakże pogląd ten wydaje się mniej rozpowszechniony (Weicher 2000).

W tym kontekście nasuwa się pytanie, czy dopłaty do kredytów hipotecznych są sprawiedliwym instrumentem polityki społecznej. Osoby najgorzej sytuowane nie skorzystają z dopłat, jeśli nie będą dysponowały minimalnym dochodem, jaki uprawnia do zaciągnięcia kredytu hipotecznego. Natomiast osoby zamożne będą w stanie uzyskać dzięki państwowym dopłatom znaczące korzyści, zwłaszcza jeśli wielkość pomocy jest proporcjonalna do wysokości dochodu i nie jest określony maksymalny próg dochodu uprawniający do skorzystania ze świadczeń.

Z punktu widzenia zagospodarowania przestrzennego wskazywano, że dopłaty do kredytów zachęcać mogą do osiedlania się na przedmieściach miast. Kwestia ta istotna jest chyba zwłaszcza w przypadku Stanów Zjednoczonych. Wiadomo nawet, że instytucje państwowe odpowiedzialne za udzielanie gwarancji do kredytów hipotecznych (które skutkowały obniżeniem ich kosztów) stosowały swego rodzaju wzorce planów osiedli podmiejskich. Preferowana byla zabudowa bardziej rozproszona i monofunkcyjna, podczas gdy w przypadku zabudowy bardziej zwartej i przemieszanej funkcjonalnie szanse na uzyskanie pomocy państwa były mniejsze.

\section{Zasady programu}

Podstawę prawną programu „Rodzina na swoim” stanowi ustawa $z$ dnia 8 września 2006 r. o finansowym wsparciu rodzin w nabywaniu własnego mieszkania. Pojęcie „rodziny” zostało użyte w tytule tegoż aktu prawnego nieprzypadkowo. Partia polityczna, będąca wówczas największą siłą w Sejmie, w kampanii wyborczej w 2005 r. akcentowała hasła polityki prorodzinnej oraz poprawy sytu- 
acji mieszkaniowej. Prawdopodobnie program „Rodzina na swoim” w założeniu łączyć miał obydwa te elementy. Do otrzymania pomocy państwa uprawnione zostały małżeństwa (niezależnie od faktu posiadania dzieci) oraz osoby samotnie wychowujące przynajmniej jedno dziecko.

Tego rodzaju ograniczenie wykluczyło $z$ katalogu beneficjentów osoby samotne (tzw. single), a także osoby żyjące $w$ związkach nieformalnych. W pewnym momencie pojawiły się nawet sugestie, że możliwość skorzystania $z$ dopłat skłoniła niektóre osoby do zawarcia związku małżeńskiego. Ograniczenie to przestało obowiązywać, gdy u władzy znalazła się partia nieakcentująca (przynajmniej w początkowym okresie) w swoim programie tak wyraźnie kwestii prorodzinnych. Po nowelizacji ustawy z lipca $2011 \mathrm{r}$. do korzystania z pomocy państwa zostały uprawnione także osoby „niepozostające w związkach małżeńskich” i niewychowujące dzieci. Były one jednak uprawnione tylko do uzyskania dopłat na zakup mieszkania, ale nie na budowę domu. Ponadto mniejsza była $w$ ich przypadku powierzchnia mieszkania, do której przysługiwała dopłata. Szczegółowe zasady programu „Rodzina na swoim” w syntetycznej formie przedstawiono w tabeli 1.

W programie "Rodzina na swoim” nie było limitów dochodu, wprowadzono jednak kilka ograniczeń, które miały zapobiec wykorzystywaniu dopłat przez osoby niebędące $w$ trudnej sytuacji mieszkaniowej. Po pierwsze, z pomocy mogły skorzystać tylko osoby, które nie byly właścicielami ani nawet najemcami mieszkania ${ }^{1}$. Po drugie, w ustawie określona została maksymalna powierzchnia mieszkania lub domu jednorodzinnego, a także maksymalna powierzchnia, do której Tabela 1. Kryteria programu dopłat do kredytów mieszkaniowych „Rodzina na swoim”

\begin{tabular}{|c|c|c|c|}
\hline Kryterium/Okres* & II faza & III faza & IV faza \\
\hline $\begin{array}{l}\text { Osoby uprawnione } \\
\text { do skorzystania } \\
z \text { dopłat }\end{array}$ & \multicolumn{2}{|c|}{$\begin{array}{l}\text { Rodziny (małżeństwa lub osoby } \\
\text { samotnie wychowujące dzieci) }\end{array}$} & $\begin{array}{l}\text { W przypadku mieszkań (nie domów) } \\
\text { także osoby nie pozostające w związkach } \\
\text { małżeńskich i nie wychowujące dzieci }\end{array}$ \\
\hline Limit wieku & \multicolumn{2}{|l|}{ Bez limitu } & $\begin{array}{l}\text { Osoby samotnie wychowujące dzieci: } \\
\text { bez limitu } \\
\text { Pozostali: } 35 \text { lat (w przypadku malżon- } \\
\text { ków - wiek mlodszego z nich) }\end{array}$ \\
\hline $\begin{array}{l}\text { Maksymalna po- } \\
\text { wierzchnia }\end{array}$ & \multicolumn{2}{|l|}{ Mieszkania: $75 \mathrm{~m}^{2}$} & $\begin{array}{l}\text { Mieszkania: } 75 \mathrm{~m}^{2} \text { (rodziny), } \\
50 \mathrm{~m}^{2} \text { (pozostali); }\end{array}$ \\
\hline & \multicolumn{2}{|c|}{ Domy jednorodzinne: $140 \mathrm{~m}^{2}$} & Domy jednorodzinne: $140 \mathrm{~m}^{2}$ \\
\hline $\begin{array}{l}\text { Maks. powierzch- } \\
\text { nia, do której przy- }\end{array}$ & \multicolumn{2}{|c|}{ Mieszkania: $50 \mathrm{~m}^{2}$} & $\begin{array}{l}\text { Mieszkania: } 50 \mathrm{~m}^{2} \text { (rodziny), } \\
30 \mathrm{~m}^{2} \text { (pozostali); }\end{array}$ \\
\hline sługiwały dopłaty & \multicolumn{2}{|c|}{ Domy jednorodzinne: $70 \mathrm{~m}^{2}$} & Domy jednorodzinne: $70 \mathrm{~m}^{2}$ \\
\hline Limit ceny & $\begin{array}{l}1,0 \times \text { koszt } \quad 1,3 \times \mathrm{KO} \\
\text { odtworzenio- } \\
\text { wy }(\mathrm{KO})\end{array}$ & $1,4 \times \mathrm{KO}$ & $\begin{array}{l}1,0 \times \text { KO dla rynku pierwotnego, } \\
0,8 \times \text { KO dla rynku wtórnego }\end{array}$ \\
\hline
\end{tabular}

* I faza - od początku programu (1 stycznia 2007 r.) do czerwca 2007 r.; II faza - od lipca 2007 r. do listopada 2008 r.; III faza - od grudnia 2008 r. do lipca 2011 r.; IV faza - od sierpnia 2011 r. do 31 grudnia $2012 \mathrm{r}$.

Źródło: opracowanie wlasne na podstawie ustawy z dnia 6 września 2006 r. o finansowym wsparciu rodzin w nabywaniu własnego mieszkania, wraz z późniejszymi zmianami.

1 Ograniczenie to dotyczylo także osób posiadających spółdzielcze wlasnościowe lub lokatorskie prawo do lokalu. 
przysługiwały dopłaty. Przykładowo zgodnie z art. 5, ust. 1, pkt 2 ustawy z dnia 8 września 2006 r. o finansowym wsparciu rodzin w nabywaniu własnego mieszkania kredytobiorca mógł zakupić mieszkanie o maksymalnej powierzchni $75 \mathrm{~m}^{2}$ lub dom jednorodzinny o powierzchni nie większej niż $140 \mathrm{~m}^{2}$, przy czym dopłaty przysługiwały tylko do powierzchni odpowiednio: $50 \mathrm{~m}^{2}$ oraz $70 \mathrm{~m}^{2}$.

Ostatnim, lecz bynajmniej nie najmniej istotnym ograniczeniem, były limity cenowe. Ceny nabywanych mieszkań nie mogły przekraczać limitów określonych w oparciu o „średni wskaźnik przeliczeniowy kosztu odtworzenia $1 \mathrm{~m}^{2}$ powierzchni użytkowej budynków mieszkalnych”. Wskaźnik ten publikowany jest okresowo przez GUS dla miast wojewódzkich oraz województw z wyłączeniem stolic. Z zastosowaniem tego rodzaju wskaźnika wiążą się pewne kontrowersje. Jego wysokość jest oczywiście zróżnicowana regionalnie, przy czym wartości dla miast wojewódzkich są wyższe niż dla reszty kraju, co w pewnym stopniu odzwierciedla ich specyfikę. Jednakże obrazuje on poziom kosztów, podczas gdy rynkowe ceny mieszkań zależą nie tyle od kosztów ich budowy, ile od relacji popytu i podaży. Stąd też wielokrotnie pojawiały się głosy, że limity cenowe programu "Rodzina na swoim” były zwłaszcza w przypadku największych miast niedostosowane do rynkowego poziomu cen.

Początkowo limity cenowe zostały ustalone na poziomie równym kosztowi odtworzenia. Tymczasem był to okres, gdy ceny mieszkań wzrastały w bardzo szybkim tempie, co nie znajdowało odbicia w publikowanych przez GUS wskaźnikach. W rezultacie $w$ pierwszych miesiącach dopłaty otrzymało bardzo niewiele osób. W czerwcu 2007 r. uchwalono nowelizację ustawy, na mocy której limity cenowe zostały zwiększone do wysokości $130 \%$ kosztu odtworzeniowego, a w listopadzie 2008 r. próg został zwiększony o kolejne 10\%. Wraz ze zwiększaniem limitów cenowych liczba osób uczestniczących $w$ programie rosła $w$ szybkim tempie. Jednakże w obliczu pogarszającej się sytuacji budżetowej „Rodzina na swoim” zaczęła być postrzegana jako zbytnie obciążenie dla finansów publicznych. W lipcu 2011 r. progi cenowe zostały znacząco obniżone. Dla nowych mieszkań maksymalna cena mogła być równa kosztowi odtworzenia, natomiast w przypadku mieszkań z rynku wtórnego wynosić mogła maksymalnie $80 \%$ tego wskaźnika. Pomimo tych daleko idących ograniczeń liczba osób korzystających z programu w 2012 r. zmniejszyła się tylko nieznacznie, podczas gdy wartość udzielonych kredytów wyraźnie spadła. Z jednej strony, mniej osób mogło skorzystać z programu z uwagi na obniżenie limitów cenowych, z drugiej zaś rozszerzył się katalog osób uprawnionych. Ponadto nieoficjalnie mówiło się już wówczas o zamiarach zaprzestania udzielania dopłat, co zapewne skłoniło część osób do przyspieszenia decyzji o zakupie mieszkania. Ostatecznie rząd podjął decyzję o zakończeniu „Rodziny na swoim” z dniem 31 grudnia 2012 r.

Kredyty z dopłatą z budżetu państwa mogły być udzielane tylko w walucie polskiej. Uniemożliwiło to uzyskanie dopłaty na kredyty zaciągnięte w walutach obcych (np. frankach szwajcarskich), które swego czasu cieszyły się dużą popularnością ze względu na niższe oprocentowanie. Można przypuszczać, że program „Rodzina na swoim” skłonił część osób do wyboru kredytu w walucie polskiej zamiast w obcej, a przez to w pewnym stopniu wpłynął na zmniejszenie ryzyka na 


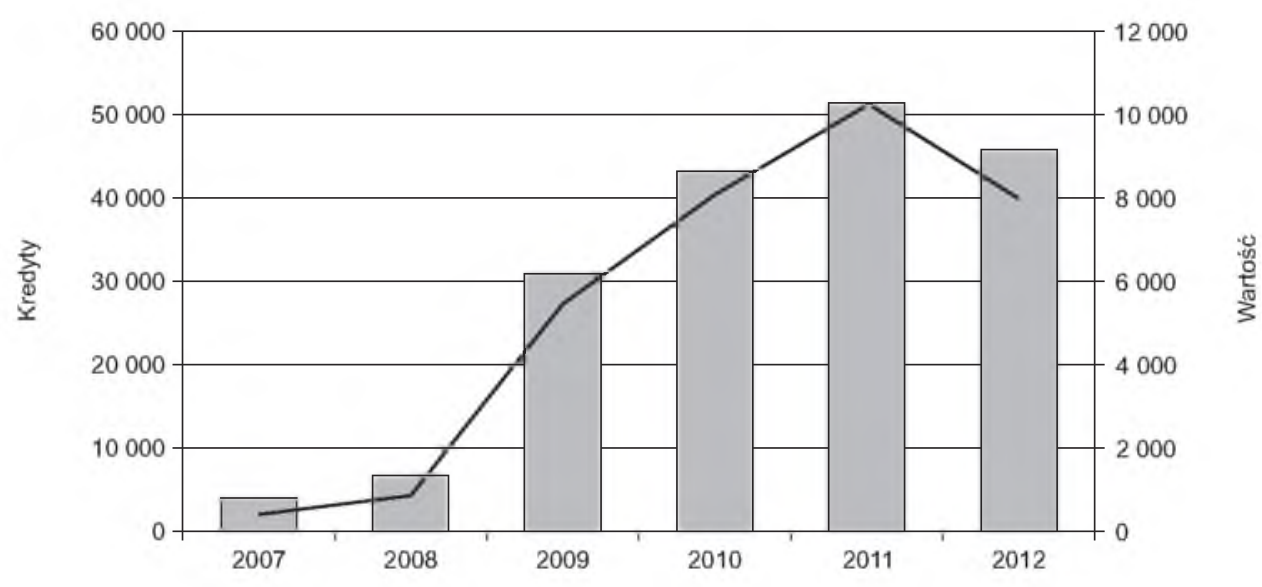

$\square$ Kredyty z dopłatą $\quad$ Wartość kredytów z dopłatą (mld PLN)

Ryc. 1. Efekty programu dopłat do kredytów mieszkaniowych w latach 2007-2012 Źródlo: opracowanie własne na podstawie danych Banku Gospodarstwa Krajowego.

rynku hipotecznym związanego z dużym uzależnieniem od zmian kursów walut (sytuacja taka miała miejsce np. na Węgrzech). Należy nadmienić, że uzyskanie dopłaty było możliwe tylko wtedy, gdy nabywane nieruchomości były zlokalizowane na terytorium RP.

Kwota dopłaty obliczana była w oparciu o pozostającą do spłaty kwotę kredytu hipotecznego, proporcjonalnie zmniejszoną, jeżeli rzeczywista powierzchnia mieszkania przekraczała maksymalną powierzchnię, do której przysługiwały dopłaty. Dopłata stanowiła 50\% odsetek naliczonych od podstawy według stopy referencyjnej. $Z$ kolei stopa referencyjna zdefiniowana została jako równowartość trzymiesięcznej stopy WIBOR powiększonej o dwa punkty procentowe ${ }^{2}$. Przykładowa kalkulacja: (1) powierzchnia mieszkania $60 \mathrm{~m}^{2}$, (2) maksymalna powierzchnia, do której przysługują dopłaty $50 \mathrm{~m}^{2}$, (3) całkowita kwota kredytu 300 tys. zł, (4) stopa WIBOR 4\%. Aby obliczyć wysokość dopłaty do pierwszej raty, obliczmy najpierw kwotę kredytu, do której przysługuje doplata. Wyniesie ona $50 \mathrm{~m}^{2} / 60 \mathrm{~m}^{2} \times 300$ tys. złotych $=250$ tys. $z$ l. Dopłata do pierwszej raty wyniesie zatem $50 \% \times(4 \%+$ $2 \%) / 12$ miesięcy $\times 250$ tys. $z \nmid=625$ zł. Wysokość dopłat do kolejnych rat ulegała zmniejszeniu proporcjonalnie do malejącej kwoty kredytu pozostałego do splaty. W sumie dopłaty przysługiwały przez okres ośmiu lat. Osoby zainteresowane uzyskaniem kredytu z dopłatą składały wnioski w jednym z banków komercyjnych, które uprzednio podpisały umowę z Bankiem Gospodarstwa Krajowego, odpowiadającym za koordynację ze strony państwa.

Kredytobiorcy znacznie częściej wykorzystywali kredyty z dopłatą do finansowania zakupu mieszkań używanych niż nowych. W latach 2007-2012 ponad połowa $(55 \%)$ całej sumy kredytów z dopłatą została przeznaczona na zakup mieszkań na rynku wtórnym, a tylko $26 \%$ na rynku pierwotnym. Kredyty na bu-

2 WIBOR - Warsaw Interbank Offered Rate, podstawowy wskaźnik określający wysokość oprocentowania pożyczek w obrocie międzybankowym w walucie polskiej. 
dowę domu jednorodzinnego stanowiły $18 \%$ całości. Taka struktura kredytów jest zapewne w największym stopniu konsekwencją przyjętych zasad. Przez większość czasu obowiązywania programu limity cenowe były określone w takiej samej wysokości zarówno dla mieszkań nowych, jak i używanych, podczas gdy ceny tych drugich są $z$ reguły niższe. Zauważalny był pewien wzrost popularności nowych mieszkań po tym, jak w 2011 r. limity zostały zróżnicowane. Jednak nawet w 2012 r. udział rynku pierwotnego wyniósł tylko 33\% (Radzimski 2014).

\section{Zróżnicowanie regionalne programu „Rodzina na swoim”}

Program „Rodzina na swoim” był w okresie swego obowiązywania jednym z najważniejszych elementów polityki mieszkaniowej w Polsce. Ogółem w latach 2007-2012 z pomocy państwa skorzystało ponad 180 tys. kredytobiorców. Kwota kredytów dofinansowanych ze środków publicznych wyniosła $33 \mathrm{mld} \mathrm{zł3}$. W odniesieniu do sumy rocznych wydatków z budżetu państwa nie są to liczby znaczące. Patrząc $z$ drugiej strony, kwota przeznaczona na doplaty jest porównywalna $z$ rocznym budżetem średniego lub nawet dużego miasta. Biorąc pod uwagę fakt, że w Polsce przeznacza się stosunkowo niewiele funduszy publicznych na politykę mieszkaniową, program „Rodzina na swoim” jawi się jako swoisty ewenement. W okresie, gdy dopłaty cieszyły się największą popularnością, około $20 \%$ wartości wszystkich kredytów mieszkaniowych udzielanych w Polsce stanowiły kredyty dofinansowane przez państwo. Wydaje się, że ze względu na nowatorski charakter programu oraz relatywnie duże znaczenie, interesująca jest odpowiedź na pytanie, jakie zróżnicowanie regionalne wykazywała pomoc udzielona przez państwo.

Podstawowy wniosek odnośnie do rozmieszczenia regionalnego jest taki, że efekty programu „Rodzina na swoim” w poszczególnych częściach Polski dość znacząco się różnią. Dotyczy to zarówno liczby umów na kredyty mieszkaniowe $z$ dopłatą zawartych $w$ ramach programu, jak i wartości tychże kredytów. Zaobserwować można pewną prawidłowość, a mianowicie zróżnicowanie regionalne „Rodziny na swoim” wykazuje podobieństwo z regionalnym zróżnicowaniem poziomu rozwoju gospodarczego. Generalnie rzecz biorąc, mieszkańcy największych miast oraz województw położonych w zachodniej i północnej części kraju w największym stopniu skorzystali z pomocy państwa w ramach programu „Rodzina na swoim". Jak wynika z badań zróźnicowania rozwoju regionalnego w Polsce, są to obszary odznaczające się najwyższym poziomem rozwoju społeczno-gospodarczego (Borowczak, Dolata 2014). Można zatem stwierdzić, że mieszkańcy bardziej zamożnych części Polski w większym stopniu skorzystali z pomocy państwa niż mieszkańcy regionów słabiej rozwiniętych. Oczywiście, od reguły tej są także pewne wyjątki. Szczególowe wyniki omówione zostały poniżej, osobno w odniesieniu do miast wojewódzkich oraz województw ( $\mathrm{z}$ wylączeniem stolic).

3 Nie jest możliwe w chwili obecnej stwierdzenie, jaka była lączna kwota dopłat, gdyż są one w dalszym ciągu wypłacane kredytobiorcom. 
Dane pozyskano ze strony internetowej Banku Gospodarstwa Krajowego. Pokazują one stan realizacji programu na dzień 31 grudnia 2012 r. Dane źródłowe obejmują informacje odnośnie do: (1) liczby umów kredytowych, dla których została przyznana dopłata z budżetu państwa, (2) łącznej wartości tychże kredytów (z uwzględnieniem dopłat). W celu przeprowadzenia analizy porównawczej dane zostały zrelatywizowane. Ostatecznie zatem w analizie wykorzystane zostały następujące wskaźniki: (1) liczba kredytów z dopłatą na 100 tys. mieszkańców, (2) przeciętna wartość kredytu z dopłatą. Pierwszy ze wskaźników mierzy skalę uczestnictwa mieszkańców danego miasta lub regionu w programie, podczas gdy drugi może być traktowany jako miara pomocy otrzymanej przez indywidualnego kredytobiorcę.

\section{Miasta wojewódzkie}

Wbrew dość rozpowszechnionej opinii, jakoby mieszkańcy największych miast w niewielkim stopniu skorzystali z „Rodziny na swoim”, to właśnie oni okazali się głównymi beneficjentami tej formy pomocy państwa. Mieszkańcy miast wojewódzkich częściej niż mieszkańcy reszty kraju korzystali z dopłat, a także uzyskiwali kredyty (a w konsekwencji dopłaty) o większej wysokości. Na miasta wojewódzkie, w których w sumie mieszka około 20\% ludności Polski, przypadła jedna trzecia wszystkich umów oraz 40\% wartości kredytów z dopłatą.

Nie tylko miasta wojewódzkie odznaczały się dominującą pozycją na tle reszty kraju, ale też w ich obrębie zauważalna była duża koncentracja dopłat w największych miastach (ryc. 2). Zarysowała się zwłaszcza bardzo silna pozycja Warszawy. Na stolicę Polski przypadło aż 30\% wartości wszystkich kredytów z dopłatą udzielonych w miastach wojewódzkich. Co interesujące, liczba dofinansowanych przez państwo kredytów mieszkaniowych w przeliczeniu na 1000 mieszkańców nie była w Warszawie - ani też w pozostałych największych miastach - szczegól-

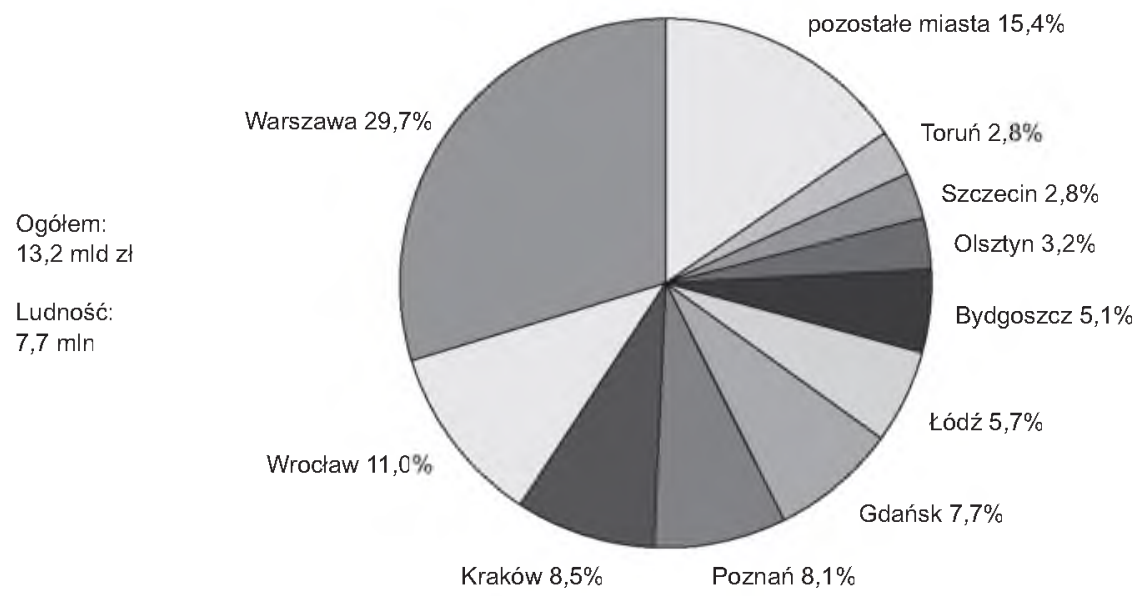

Ryc. 2. Wartość kredytów z dopłatą w podziale na miasta wojewódzkie

Źródło: opracowanie własne na podstawie danych Banku Gospodarstwa Krajowego. 
nie duża. Tak wysoka wartość kredytów udzielonych w stolicy wynika natomiast z faktu, że przeciętna wartość kredytu była zdecydowanie wyższa niż w innych częściach kraju. Warszawa była jedynym miastem, w którym przeciętna wartość kredytu z dopłatą wyniosła ponad 300 tys. zł.

Na następnych pozycjach znalazły się inne duże miasta, przy czym ich kolejność niekoniecznie zgodna była z uszeregowaniem według liczby ludności. Mianowicie tuż za Warszawą uplasował się Wrocław, gdzie przyznano kredyty z dopłatą - łącznej wartości stanowiącej $11 \%$ całkowitej sumy dla miast wojewódzkich. Dopiero za Wrocławiem znalazł się Kraków, a tuż za nim Poznań i Gdańsk. Można domniemywać, że słabszy wynik Krakowa w porównaniu z Wrocławiem wynika z faktu, że stolica Małopolski odznacza się bardzo wysokim poziomem cen mieszkań, przez co zainteresowanym osobom trudno było znaleźć lokale spełniające kryteria cenowe programu „Rodzina na swoim”. Mimo wszystko jednak wartość kredytów z dopłatą, jakie uzyskali wnioskodawcy z Krakowa, była niemal o połowę większa niż w Łodzi, która jest miastem podobnej wielkości. Jest to zapewne odzwierciedlenie relatywnie słabszego poziomu rozwoju łódzkiego rynku mieszkaniowego. Także przeciętna wielkość kredytu z dopłatą, która wyniosła w Łodzi niewiele ponad 150 tys. zł, znacznie odbiegała od poziomu w innych największych miastach. Przeciętna wartość kredytu była niższa tylko w Katowicach, Zielonej Górze i Gorzowie Wielkopolskim.

Spośród mniejszych miast wojewódzkich kilka wyróżniło się relatywnie wysokim poziomem udziału w programie. Zwraca uwagę zwłaszcza Olsztyn, gdzie udzielono rekordowo wysokiej liczby kredytów z dopłatą w przeliczeniu na 100 tys. mieszkańców. Dzięki temu całkowita wartość kredytów, jakich udzielono w Olsztynie, była wyższa niż w większych miastach, takich jak Szczecin czy Katowice. Natomiast najmniejszej liczby kredytów w ramach programu „Rodzina na swoim” udzielono w Opolu. Było to jedyne miasto wojewódzkie, w którym liczba kredytów mieszkaniowych dofinansowanych przez państwo nie przekroczyła tysiąca.

Przeciętna wielkość kredytu z dopłatą wykazuje w przypadku miast wojewódzkich duże zróżnicowanie. Różnica pomiędzy miastem o najwyższej kwocie kredytu oraz miastem, w którym kwota kredytu była najniższa, jest dwukrotna. Oprócz wspomnianej już Warszawy, która zdecydowanie wyróżniała się na tle innych miast pod względem wartości kredytów z dopłatą, w czołówce znalazły się także Wrocław, Kraków, Gdańsk i Poznań. We wszystkich wymienionych miastach przeciętna wartość kredytu znacznie przekroczyła 200 tys. zł (w przypadku Warszawy - nawet 300 tys. zł). Wynik ten interpretować należy jako odzwierciedlenie sytuacji na rynkach mieszkaniowych w największych polskich miastach. Wysokie ceny mieszkań przełożyły się na wysokie kwoty kredytów mieszkaniowych, a w konsekwencji na wysokie dopłaty z budżetu państwa. Z drugiej strony, zwraca uwagę niska przeciętna wartość kredytu w tradycyjnych ośrodkach przemysłowych - Łodzi oraz Katowicach. Co znamienne, kilka znacznie mniejszych miast cechowało się wyższą przeciętną wartością kredytu niż dwa wymienione ośrodki. Sugeruje to, że charakterystyka rynków mieszkaniowych Łodzi i Katowic jest dość odmienna niż innych największych polskich miast. 
Poziom uczestnictwa w programie „Rodzina na swoim” był, podobnie jak przeciętna wielkość kredytu z dopłatą, dość zróżnicowany w poszczególnych miastach wojewódzkich. Najniższy poziom uczestnictwa to 500 dofinansowanych kredytów na 100 tys. mieszkańców, podczas gdy poziom najwyższy był ponaddwukrotnie większy i przekraczał 1200 kredytów na 100 tys. ludności.

W przypadku miast wojewódzkich nie zarysowuje się wyrazista pozytywna korelacja pomiędzy liczbą kredytów z dopłatą na 100 tys. mieszkańców a ich przeciętną wartością (ryc. 3). Co więcej, niektóre mniejsze miasta, gdzie wartość kredytu była umiarkowanie wysoka, odznaczały się wyraźnie wyższym stopniem uczestnictwa w programie niż miasta największe. Oprócz wspomnianego już Olsztyna dobrze prezentowały się pod tym względem Bydgoszcz, Toruń, Gorzów Wielkopolski i Zielona Góra. We wszystkich tych miastach liczba kredytów z dopłatą była zblżeona lub nawet wyższa niż 1000 na 100 tys. mieszkańców, podczas gdy w Warszawie było to mniej niż 800, a w Krakowie tylko 600. Wydaje się, że zwłaszcza w przypadku stolicy Małopolski zaznaczył się negatywny wpływ limitów cenowych niedostosowanych do realiów rynkowych. Niemożność znalezienia mieszkania, które spełniałoby kryteria, wykluczyła część osób z możliwości otrzymania pomocy państwa.

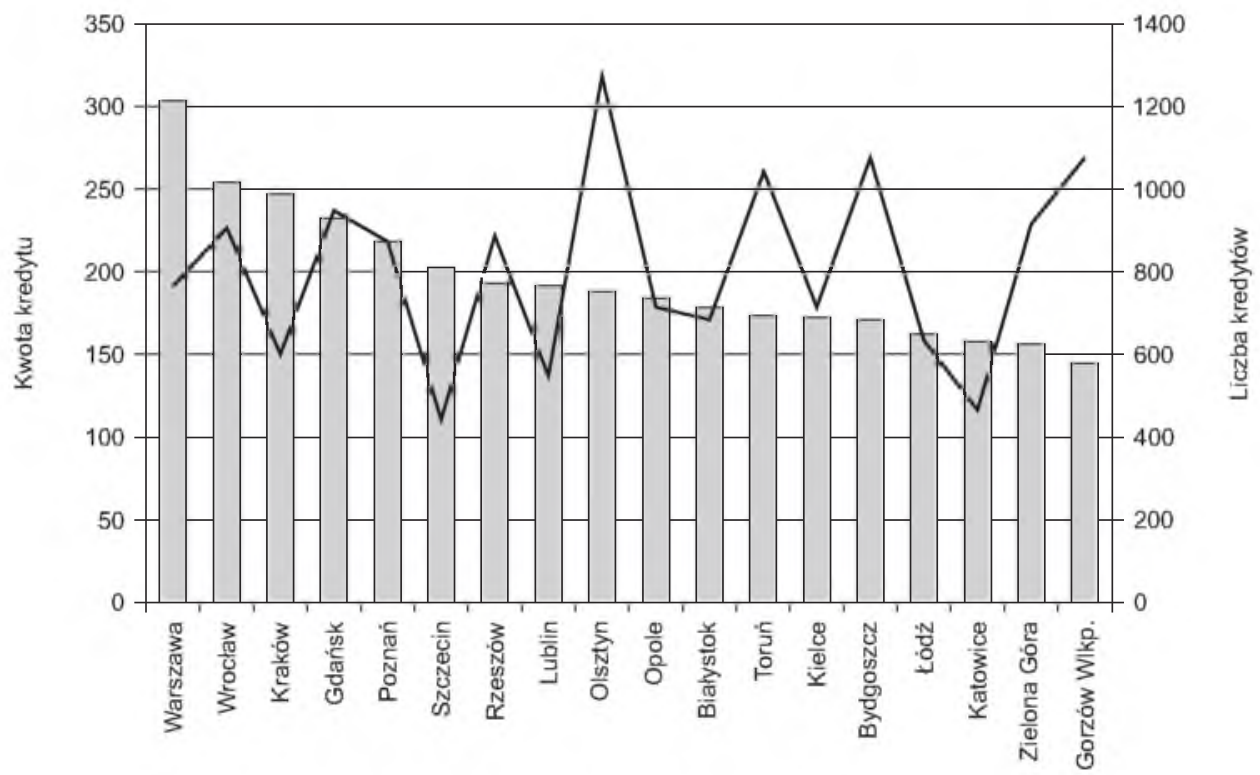

Przeciętna kwota kredytu (tys. PLN) — Liczba kredytów na 100 tys. mieszkanców

Ryc. 3. Zróżnicowanie efektów programu „Rodzina na swoim” w miastach wojewódzkich Źródło: opracowanie własne na podstawie danych Banku Gospodarstwa Krajowego. 


\section{Województwa}

Dane dotyczące programu „Rodzina na swoim” dostępne są dla miast wojewódzkich oraz obszarów województw z wyłączeniem stolic. W powyższej części artykułu omówiono wyniki dla miast wojewódzkich, natomiast w kolejnych akapitach zaprezentowane zostaną wyniki w odniesieniu do obszarów województw z wyłączeniem stolic. Jednakże ze względu na zwartość struktury tekstu w odniesieniu do ww. obszarów używane będzie pojęcie „województwo”.

Rozkład efektów programu „Rodzina na swoim” był w przypadku województw bardziej wyrównany niż w przypadku miast wojewódzkich (ryc. 4). Podczas gdy Warszawa zdecydowanie wyprzedziła pozostałe miasta pod względem wartości udzielonych kredytów z dopłatą, województwo mazowieckie zajęło wprawdzie pierwsze miejsce, lecz z nieznaczną przewagą nad innymi województwami. Pięć województw, które otrzymały kredyty o najwyższej wartości, uzyskało łącznie $54 \%$ sumy dla województw, natomiast na pięć pierwszych miast wojewódzkich przypadło $66 \%$ całkowitej wartości kredytów dla tej kategorii. Także w odniesieniu do przeciętnej wartości kredytu z dopłatą oraz liczby kredytów przypadającej na 100 tys. mieszkańców rozrzut wartości w przypadku województw był znacznie mniejszy niż w przypadku miast wojewódzkich.

Drugie pod względem całkowitej wartości przyznanych kredytów z dopłatą miejsce (po województwie mazowieckim) przypadło województwu śląskiemu. Wynik ten wiązać należy przede wszystkim z faktem, że obszar tegoż województwa obejmuje największą w Polsce konurbację miejską. Jest to województwo o zdecydowanie najwyższym wskaźniku urbanizacji, a ludność miejska w większym stopniu niż wiejska korzystała z programu „Rodzina na swoim”. Śląskie jest także najludniejszym województwem, jeżeli pominie się ludność stolic województw.

Uszeregowanie województw według wartości przyznanych kredytów z dopłatą niekoniecznie pokrywa się z ich kolejnością według liczby ludności. Pozy-

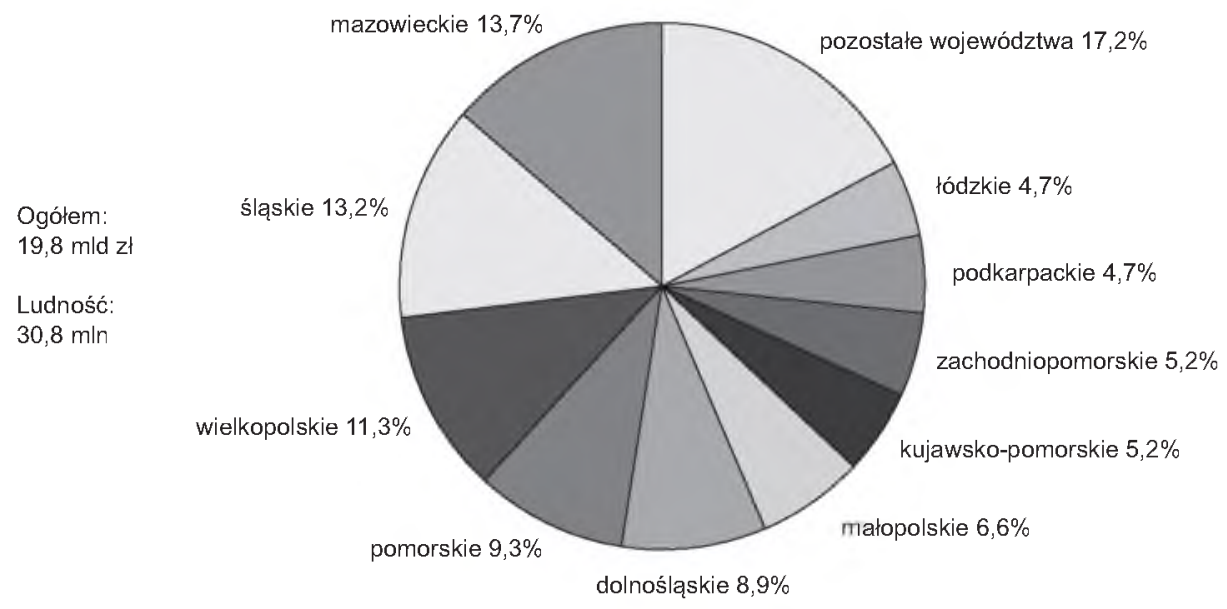

Ryc. 4. Wartość kredytów z dopłatą w podziale na województwa (bez stolic)

Źródło: opracowanie własne na podstawie danych Banku Gospodarstwa Krajowego. 
tywnie wyróżnia się zwłaszcza województwo pomorskie, które wyprzedza pod względem wartości kredytów większe województwa: dolnośląskie i małopolskie. Wynika to zapewne z faktu, że obszar tego województwa obejmuje aglomerację trójmiejską. Zastanawiający jest dobry wynik województwa zachodniopomorskiego, gdzie budownictwo mieszkaniowe koncentruje się głównie na przedmieściach Szczecina oraz $w$ pasie nadmorskim, przy czym $w$ tym drugim przypadku kredyty z dopłatą nie były raczej wykorzystywane na dużą skalę, ponieważ mieszkania traktowane jako „drugie domy” nie spełniały kryteriów programu. Bardziej szczegółową analizę można by przeprowadzić, gdyby dane dotyczące wyników programu „Rodzina na swoim” były dostępne na niższym poziome dezagregacji terytorialnej (np. dla powiatów). Skala uczestnictwa w programie dopłat w przypadku większości województw nie była bardzo zróżnicowana. Liczba przyznanych kredytów z dopłatą w przeliczeniu na 100 tys. mieszkańców wahała się od 300 do 550 . Wśród województw, w których uczestnictwo w programie było na najniższym poziomie, znalazły się głównie województwa o charakterze rolniczym, zlokalizowane na wschodzie lub południu Polski. Województwa Polski centralnej i zachodniej cechowały się nieco wyższym i mało zróżnicowanym poziomem uczestnictwa w programie. Zdecydowanie wyróżniało się jedynie województwo pomorskie, gdzie liczba kredytów z dopłatą w przeliczeniu na 100

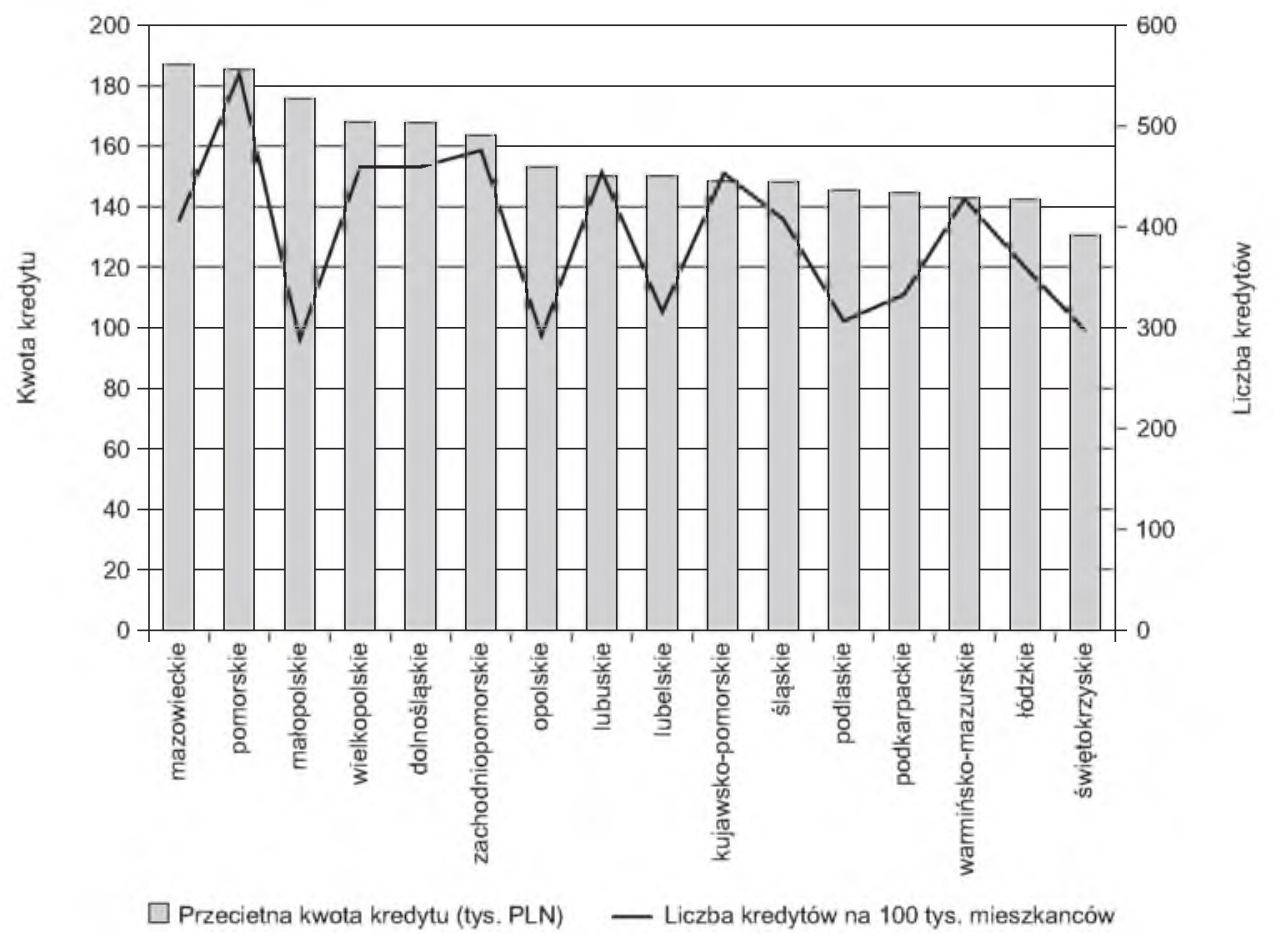

Ryc. 5. Zróżnicowanie efektów programu „Rodzina na swoim” w województwach (bez stolic)

Źródło: opracowanie własne na podstawie danych Banku Gospodarstwa Krajowego. 
Kredyty $z$ dopłatą na 100 tys. osób:

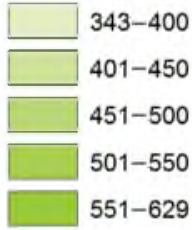

\section{Udział kredytów:}

Miasto/miasta wojewódzkie

Pozostała część województwa

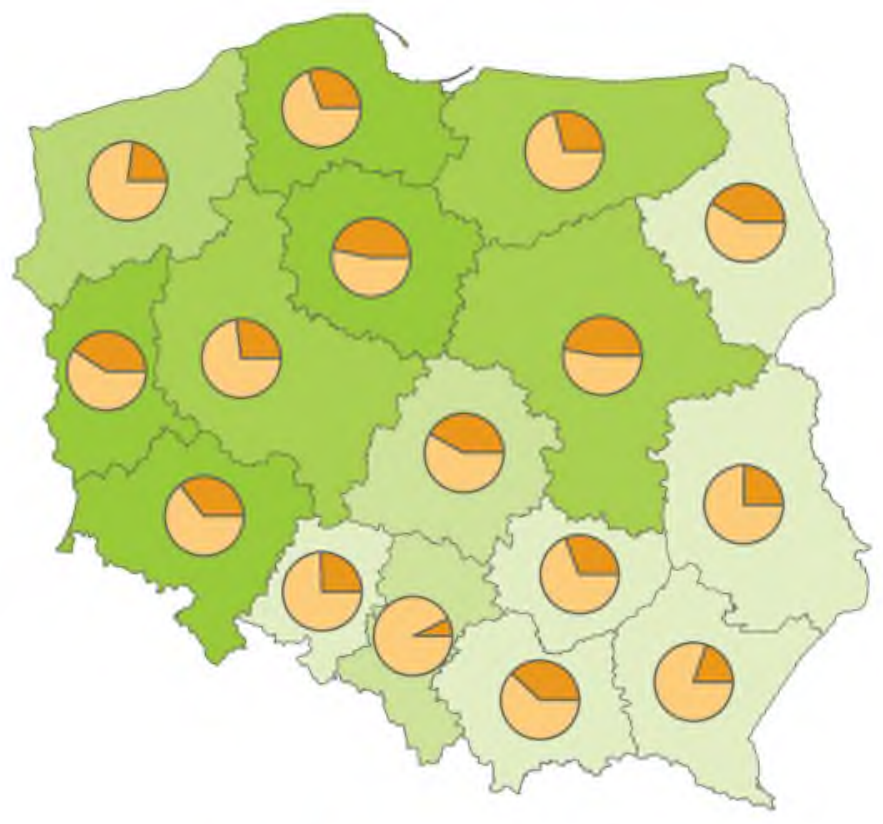

\section{Przeciętna kwota kredytu z dopłatą (tys. zł):}
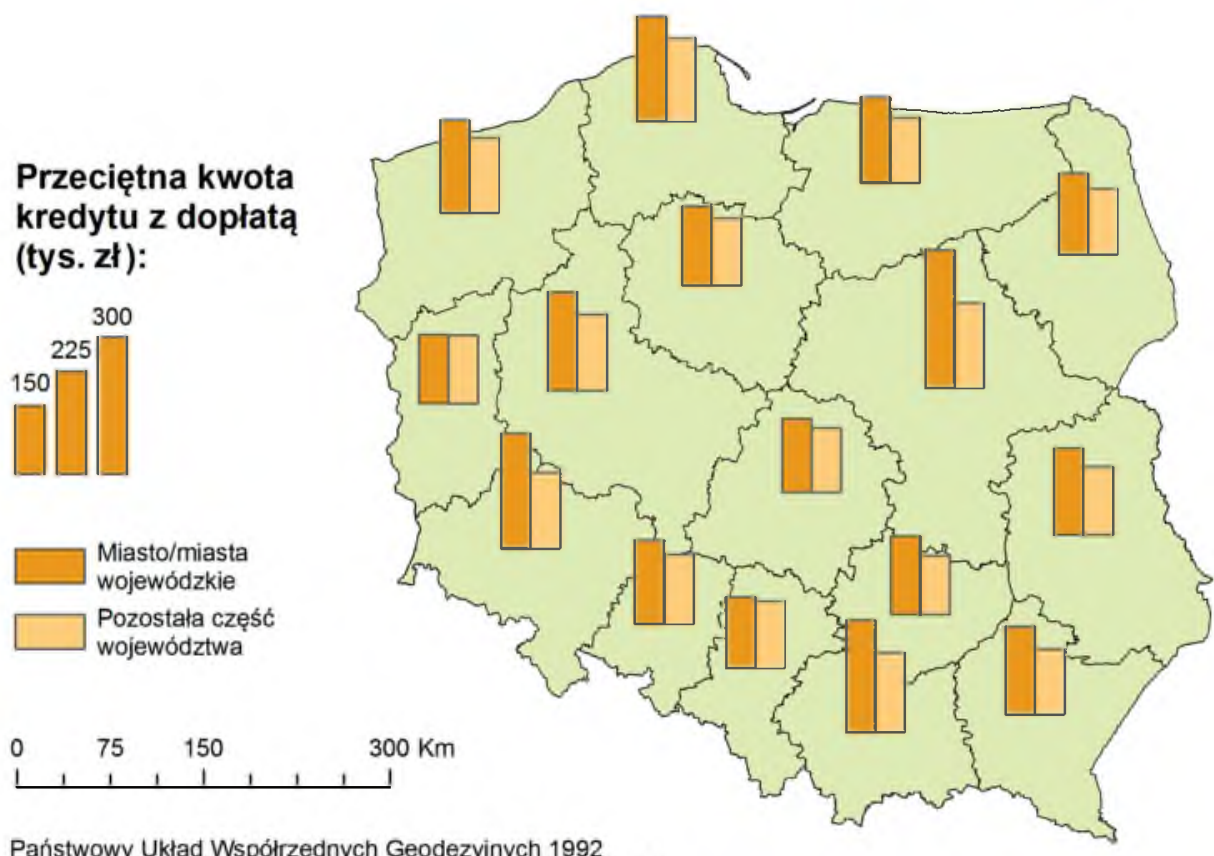

Państwowy Układ Współrzędnych Geodezyjnych 1992 oparty na odwzorowaniu Gaussa-Krügera (kod EPSG $\$ 2180$ )

Ryc. 6. Regionalne zróżnicowanie programu „Rodzina na swoim” - synteza Źródło: opracowanie własne na podstawie danych Banku Gospodarstwa Krajowego. 
tys. mieszkańców była wyraźnie wyższa niż w pozostałych województwach. Relatywnie wysokie wskaźniki uczestnictwa występowały w województwach „ziem odzyskanych", co być może wiąże się z mniejszą rolą tradycyjnego rolnictwa. Mieszkańcy tych województw mogą w mniejszym stopniu korzystać w zaspokajaniu własnych potrzeb mieszkaniowych $z$ pomocy rodziny, $w$ większym stopniu natomiast z pomocy państwa.

Przeciętna wielkość kredytu z dopłatą, podobnie jak liczba kredytów w przeliczeniu na 100 tys. mieszkańców, była w przypadku większości województw umiarkowanie zróżnicowana. Najniższa przeciętna wartość kredytu wyniosła 130 tys. zł, najwyższa natomiast 190 tys. zł. Pod względem przeciętnej wartości kredytu na pierwszym miejscu uplasowało się województwo mazowieckie. Warto przy tym odnotować, że skala uczestnictwa w programie „Rodzina na swoim” w tym województwie nie była szczególnie duża. Wyniki te sugerują, że z dopłat korzystali głównie mieszkańcy przedmieść Warszawy, w mniejszym stopniu zaś mieszkańcy pozostałej części województwa. Na drugim miejscu za województwem mazowieckim sytuowało się województwo pomorskie. Tylko w tych dwóch województwach przeciętna wartość kredytu przekroczyła 180 tys. zł. Także województwa: małopolskie, wielkopolskie, dolnośląskie i zachodniopomorskie charakteryzowały się wysoką przeciętną wartością kredytu.

W przypadku województw zauważalna jest pewna prawidłowość, która nie występowała w odniesieniu do miast wojewódzkich. Mianowicie przeciętna wielkość kredytu z dopłatą wykazuje pozytywną korelację z liczbą kredytów przypadającą na 100 tys. mieszkańców (ryc. 5). Od reguły tej są wyjątki, jednakże, generalnie rzecz ujmując, województwa zlokalizowane w północnej i zachodniej części kraju, a zwłaszcza te, których stolicami są największe miasta (z czym wiąże się intensywna suburbanizacja), odznaczały się wysokimi wartościami obydwu wskaźników. W szczególności były to województwa: dolnośląskie, pomorskie i wielkopolskie. Natomiast w przypadku większości województw zaliczanych do regionów „ściany wschodniej” zarówno uczestnictwo w programie, jak i przeciętna kwota kredytu $z$ dopłatą były na niskim poziomie.

Reasumując, do głównych beneficjentów programu „Rodzina na swoim” zaliczyć można mieszkańców największych miast oraz regionów najbardziej rozwiniętych, zaś mieszkańcy regionów mniej zamożnych skorzystali z tej formy pomocy w znacznie mniejszym stopniu (ryc. 6).

\section{Wnioski}

W niniejszym artykule przedstawiono regionalne zróżnicowanie pomocy państwa udzielonej w ramach programu „Rodzina na swoim”. Wyniki pokazują, że zarówno liczba kredytów z dopłata, jak ich wartość były w poszczególnych częściach Polski dość mocno zróżnicowane. Generalnie w największym stopniu z dopłat do kredytów mieszkaniowych skorzystali mieszkańcy miast wojewódzkich oraz województw zachodniej i północnej części kraju, a w najmniejszym mieszkańcy regionów „ściany wschodniej” oraz południowej Polski. 
Fakt, że pomoc państwa udzielona w ramach programu „Rodzina na swoim” w znacznej części skoncentrowana była w największych miastach oraz bardziej zamożnych regionach Polski, może być interpretowany dwojako. Z jednej strony, $z$ dopłat częściej korzystano tam, gdzie jest większe zapotrzebowanie na kredyty hipoteczne. Specyfika rynku mieszkaniowego w dużych miastach sprawia, że ta forma finansowania potrzeb mieszkaniowych stosowana jest tam bardzo często. Dla porównania na obszarach wiejskich relatywnie większą rolę odgrywają zapewne transfery międzypokoleniowe, częściej także wykorzystywany jest własny wkład pracy.

$Z$ drugiej strony, patrząc z punktu widzenia sprawiedliwości społecznej, można stwierdzić, że pomoc państwa trafiła w dużej części do osób raczej sytuujących się powyżej średniego krajowego poziomu dochodów. Nie można zatem w tym przypadku mówić o polityce, która byłaby ukierunkowana na wsparcie osób znajdujących się w najtrudniejszej sytuacji mieszkaniowej. Program „Mieszkanie dla młodych”, będący swego rodzaju kontynuacją „Rodziny na swoim", będzie prawdopodobnie jeszcze bardziej skoncentrowany w dużych miastach. Warunkiem otrzymania dopłaty w tym programie jest bowiem nabycie mieszkania na rynku pierwotnym (od dewelopera).

Kwestią sporną o dość zasadniczym znaczeniu jest, czy polityka redystrybucji funduszy publicznych winna mieć na celu wsparcie miast lub regionów najsłabszych, czy też przeciwnie, wspierać należy raczej obszary wzrostu, licząc na to, że „pociągną" za sobą resztę. Wśród decydentów brak zgodności w tej kwestii, tym bardziej, że problem ma wyraźny wymiar polityczny. Za przykład może posłużyć polityka spójności Unii Europejskiej, która - ku niewątpliwej korzyści Polski i pozostałych nowych państw członkowskich - w okresie od 2004 r. była wyraźnie ukierunkowana na wsparcie regionów najsłabiej rozwiniętych. Ten kierunek wsparcia kontynuowany jest także $\mathrm{w}$ nowej perspektywie finansowej UE na lata 2014-2020, jednak obecnie silniej akcentowana jest rola aglomeracji miejskich jako głównych motorów wzrostu gospodarczego.

Program „Rodzina na swoim” był zatem swego rodzaju polityką miejską w kraju, w którym dopiero tworzone są zręby polityki miejskiej sensu stricto. Nasuwa się jednakże pytanie, czy właśnie tego rodzaju pomocy ze strony państwa miasta potrzebują najbardziej. Dopłaty do kredytów, skłaniając młodych ludzi do kupowania mieszkań, jednocześnie silniej wiążą ich z danym miejscem. Tymczasem w obecnych realiach rynku pracy pożądaną cechą jest mobilność pracowników, w tym gotowość do podjęcia pracy w innym mieście. Tego rodzaju relokacje są łatwiejsze, gdy istnieje rozbudowany rynek najmu mieszkań. Tymczasem Polska jest wśród państw czlonkowskich UE jednym z krajów, gdzie rynek najmu jest najsłabiej rozwinięty. Być może właśnie w tym kierunku winna zmierzać pomoc państwa, gdyż jak dotąd dla ożywienia budownictwa mieszkań na wynajem uczyniono raczej niewiele. 


\section{Podziękowania}

Autor pragnie złożyć serdeczne podziękowania uczestnikom warsztatów dotyczących polityki mieszkaniowej w krajach postsocjalistycznych, które odbyły się w maju 2013 r. w Sztokholmie, a zwłaszcza organizatorom: prof. Sashy Tsenkovej i dr Dominice Polańskiej, a także dwóm anonimowym recenzentom za cenne uwagi, które pomogły w udoskonaleniu artykułu.

\section{Literatura}

Andrews D., Sánchez A.C. 2011. The evolution of homeownership rates in selected OECD countries: Demographic and public policy influences. OECD Journal: Economic Studies, 2011(1): 207-243.

Benchetrit G., Czamanski D. 2009. Immigration and home ownership: Government subsidies and wealth distribution effects in Israel. Housing, Theory and Society, 26(3): 210-230.

Berger T., Englund P., Hendershott P.H., Turner B. 2000. The capitalization of interest subsidies: Evidence from Sweden. Journal of Money, Credit and Banking, 32(2): 199-214. Borowczak A., Dolata M. 2014. Rozkład obszarów wzrostu i obszarów stagnacji gospodarczej w Polsce w latach 2000-2010. Rozwój Regionalny i Polityka Regionalna, 25: 47-68.

Bourassa S.C., Yin M. 2008. Tax deductions, tax credits and the homeownership rate of young urban adults in the United States. Urban Studies, 45(5-6): 1141-1161.

Bourassa S.C., Peng C.W. 2011. Why is Taiwan's homeownership rate so high? Urban Studies, 48(13), 2887-2904.

Donner C. 2002. Housing policies in the European Union. Theory and practice. Wydane nakładem autora, Wiedeń.

Frąckowiak M. 2008. Ekonomiczne i społeczne problemy polskiego mieszkalnictwa. Wydawnictwo PTPN, Poznań.

Hamby C. 2011 . Literature review: the economic benefits of homeownership for low-income households (http://www.academia.edu/1825697/Literature_Review_Homeownership_Promotion_in_ Public_Policy; dostęp: 25.09.2013).

Hanson A. 2012. The incidence of the mortgage interest deduction: Evidence from the market for home purchase loans. Public Finance Review, 40(3): 339-359.

Hegedüs J., Lux M., Sunega P. 2011. Decline and depression: The impact of the global economic crisis on housing markets in two post-socialist states. Journal of Housing and the Built Environment, 26(3): 315-333.

Lis P. 2008. Polityka państwa w zakresie finansowania inwestycji mieszkaniowych. Wydawnictwo C.H. Beck, Warszawa.

Ministry of the Interior and Kingdom Relations of the Netherlands 2010. Housing Statistics in the European Union 2010. The Hague. Edited by Kees Dol and Marietta Haffner (http://www.bmwfj. gv.at/Wirtschaftspolitik/Wohnungspolitik/Documents/housing_statistics_in_the_european_ union_2010.pdf; dostęp 27.04.2013.

Radzimski A. 2014. Subsidized mortgage loans and housing affordability in Poland. GeoJournal, 79 : 467-494.

Weicher J.C. 2000. Comment on Steven C. Bourassa and William G. Grigsby's, "Income tax concessions for owner-occupied housing". Housing Policy Debate, 11 (3): 547-559. 


\section{Regional differentiation of housing policy. The example of "Family's own home" policy}

Summary: Although the housing market in Poland has developed very dynamically since the fall of socialism, the overall housing situation still remains rather unsatisfactory. In 2006 the government initiated a new policy of mortgage loan subsidies. The popular name of this policy is "Family's own home" (pol. „Rodzina na swoim”). The name comes from the fact that initially only families (i.e. married couples or lone parents) were eligible to receive support, however this limitation was later raised. The purpose of this paper is to investigate the regional differentiation of the outcomes of the "Family's own home" policy. We look at the distribution of subsidized mortgage loans in 16 regions (voivodships) and 18 regional capital cities. Both the number and value of loans are considered, and the temporal coverage is from 2007 to 2012. Results lead to the conclusion that regional capital cities benefited more from public support than other areas, and regions located in the western and northern part of Poland received more subsidies than these located in east and south. In other words, there was in general a positive correlation between the level of socio-economic development, and the amount of public funds received by particular cities or regions. That relationship might be interpreted in different ways. On the one hand, one could argue that a major part of government support was utilized where it was mostly needed, since housing markets in cities are characterized by higher turnover rates, and mortgage loans tend to be a more popular way of housing financing in cities than in rural areas. On the other hand, the "Family's own home" program did not substantially improve the housing situation of those mostly in need. Rather, the main beneficiaries were households somewhat above the average income.

Key words: housing policy, mortgage loans, regional differentiation, regional development 